\section{Temperature and Seed Moisture Govern Storage Duration and Germination of Phlox drummondii}

\author{
W.J. Carpenter, E.R. Ostmark, and J.A. Cornell ${ }^{1}$ \\ Department of Environmental Horticulture, Institute of Food and Agricultural \\ Sciences, University of Florida, Gainesville, FL 32611
}

Additional index words. germination temperatures, seed desiccation, storage temperature, relative humidity

\begin{abstract}
Phlox drummondii Hook seed germinated well over a wide range of constant or alternating temperatures. Germination percentages at constant temperatures of 10 to $25 \mathrm{C}$ ranged from $94 \%$ to $98 \%$ for 'Light Salmon' and from $83 \%$ to $88 \%$ for 'Deep Salmon'. No seeds germinated at constant $30 \mathrm{C}$. Total germination percentages at alternating temperatures ranged from $93 \%$ to $99 \%$ for 'Light Salmon' and $67 \%$ to $82 \%$ for 'Deep Salmon'. For both cultivars, the number of days to $50 \%$ of final germination $\left(T_{50}\right)$ and between $10 \%$ and $90 \%$ germination $\left(T_{90}-T_{10}\right)$ decreased as constant temperatures or the median for alternating temperatures rose from 10 to $20 \mathrm{C}$. The seeds had only limited desiccation tolerance. Reducing the moisture content of stored seed from $9 \%$ to $5 \%$ did not reduce total germination significantly, but $5 \%$ to $6 \%$ seed moisture levels increased the days to $T_{50}$ and $T_{90}-T_{10}$ compared with higher moisture contents. The relative humidity and temperature that phlox seed received during long-term storage influenced germination. After seed was stored at $5 \mathrm{C}$, germination generally was higher, earlier, and more uniform than after storage at 15 or $25 \mathrm{C}$. The highest total germination percentages and shortest $T_{50}$ and $T_{90}-T_{10}$ occurred following storage for 12 months at $5 \mathrm{C}$ and $20 \%$ to $40 \%$ relative humidity.
\end{abstract}

Annual phlox are colorful landscape plants, and recently introduced dwarf strains are gaining popularity as flowering bedding plants. Temperature is critical for maximum germination; Ball (1985) recommends 16C and Shirokova et al. (1977) recommend 20C. Cathey (1976) reported that continuous darkness was required to achieve maximum total germination. Jana and Dass (1984) found that pretreating phlox seed by soaking them in growth regulator solutions increased subsequent germination in darkness. Heydecker and Hendy (1975) reported that priming Phlox drummondii seed in $33.4 \%$ polyethylene glyco1 8000 at $15.5 \mathrm{C}$ for 14 days promoted faster and more uniform germination. Research on storing annual phlox seed has not been conducted. Our research objectives were to compare germination at constant and alternating temperatures, determine the effects of desiccation on seed viability, and measure temperature and relative humidity $(\mathrm{RH})$ interactions during seed storage.

Seed handling and germination procedures. Seeds of 'Light Salmon' and 'Deep Salmon' Phlox Palona were received from Sluis and

Received for publication 27 July 1992. Accepted for publication 12 Nov. 1992. Florida Agricultural Experiment Station Journal Series no. R-2539. This research was sponsored partially by a grant from the Bedding Plants Foundation, Lansing, Mich. The cost of publishing this paper was defrayed in part by the payment of page charges. Under postal regulations, this paper therefore must be hereby marked advertisement solely to indicate this fact.

'Dept. of Statistics.
Groot Quality Seeds, Enkhuizen, Holland, 6 Nov. 1990, 4 weeks after harvest. Seeds were dusted with 3a, 4, 7, 7a-tetrahydro-2-[(trichloromethyl)thiol]- $1 \mathrm{H}$-isoindole- $1,3(2 \mathrm{H})$ dione (captan). Experimental units consisted of four 100-seed replicates, which were germinated in individual $9-\mathrm{cm}$ petri dishes on a double layer of Whatman no. 1 filter paper moistened with $6 \mathrm{ml}$ of distilled water. Seeds were germinated in incubators (Stults Scientific Engineering Corp, Springfield, Ill.) at constant or 12-h alternating temperatures. In each study, germination percentage $(\mathrm{G})$, days to $50 \%$ of final germination $\left(\mathrm{T}_{50}\right)$, and germination span in number of days between $10 \%$ and $90 \%$ germination $\left(\mathrm{T}_{90}-\mathrm{T}_{10}\right)$ were calculated as described by Furutani et al. (1985).

Germination temperature. 'Light Salmon' and 'Deep Salmon' seeds were germinated in petri dishes placed in dark incubators at constant $10,15,20,25$, or $30 \mathrm{C}$. In a second study, seeds were stored at $5 \mathrm{C}$ for 3 weeks before they were germinated in darkness at $12-\mathrm{h}$ alternating temperatures of $10 / 15 \mathrm{C}, 10 / 20 \mathrm{C}$, $15 / 20 \mathrm{C}, 15 / 25 \mathrm{C}$, or $20 / 25 \mathrm{C}$. Seeds with radicles emerged through the testa were counted daily. Trends across the temperatures were determined for $G, T_{50}$, or $T_{90}-T_{10}$ by fitting the data using polynomial regression equations. The criterion used for determining the best-fitting regression equation was to perform a significance test on the coefficient estimate of the highest-degree term in the model. A curvilinear trend was detected by finding a significant $(P<0.05)$ quadratic coefficient estimate. A trend that was not curvilinear but strictly linear was detected by fitting a simpler model form and finding a significant $(P<0.05)$ linear or slope coefficient estimate.

Seed moisture content. The seed replications of both cultivars were weighed, placed in 9 -cm open petri dishes, and dehydrated for 1 , $6,12,24,48$, or $72 \mathrm{~h}$ in $40 \mathrm{C}$ forced-draft ovens. After being dehydrated, each replication was reweighed and immediately sealed in screwcapped 10-ml glass vials, 100 seeds per vial, and stored at 5C for 3 weeks. After storage, seeds were reweighed and germinated in darkness at constant 20C as previously described. Seeds with emerged radicles were counted daily, and germination data were analyzed by fitting the data using polynomial regression equations. When the seeds were received, four 100-seed lots of each cultivar were weighed, dehydrated at $105 \mathrm{C}$ for $48 \mathrm{~h}$, and reweighed after they had cooled to determine the initial moisture content.

Temperature and RH interactions during seedstorage. 'Light Salmon' seeds were stored in $15-\times 2.5-\mathrm{cm}$ petri dishes on wire screens supported by segments of tubing $1 \mathrm{~cm}$ above a chemical-desiccant. Humidity was controlled using $50-\mathrm{ml}$ of saturated lithium chloride, magnesium chloride, magnesium nitrate, sodium chloride, or potassium nitrate to achieve $11 \%, 34 \%, 52 \%, 75 \%$, or $95 \% \mathrm{RH}$, respectively (Copeland, 1976). Incubators with refrigeration and heating capacities maintained a constant 5,15 , or $25 \mathrm{C}$ during $3,6,9$, or 12 months of seed storage. After storage, seeds from all treatments were germinated in darkness at 20C as described previously. Also, groups of four replications of 100 seeds each were desiccated for $48 \mathrm{~h}$ in forced-draft ovens at $105 \mathrm{C}$ to determine seed moisture content after storage at each RI-I. The design was a $5 \times$ $3 \times 4$ factorial with four replicates of each treatment. The data were tested by analysis of variance and fitting multiple regression equations using SAS's PROC REG program (SAS, 1985) to determine the effects of temperature, storage period (SP), and RH on germination. Initially, the model that was fitted at each level of storage temperature was a complete second-degree polynomial: Response $=\beta_{0}+\beta_{1} \mathrm{SP}+\beta_{2} \mathrm{RH}+\beta_{3} \mathrm{SP} \times \mathrm{RH}+\beta_{4} \mathrm{SP}^{2}+$ $\beta_{5} \mathrm{RH}^{2}+\mathrm{E}$, where $\beta_{1} S P$ and $\beta_{2} \mathrm{RH}$ represent the linear effects of SP and $\mathrm{RH}$, respectively, on the response; $\beta_{3} \mathrm{SP} \times \mathrm{RH}$ represents a linearby-linear interaction effect between SP and $\mathrm{RH}$; and $\mathrm{B}_{4} \mathrm{SP}^{2}$ and $\beta_{5} \mathrm{RH}^{2}$ represent the curvilinear (quadratic) effects of SP and RH. Higherdegree terms that did not attain a significance level of $P=0.05$, such as $\beta_{4} \mathrm{SP}^{2}$ and $\beta_{5} \mathrm{RH}^{2}$, were dropped to produce simpler, reduced model forms in some cases. Plots of the estimated germination surfaces were generated using the CONTOUR function in the S language (Becker et al., 1988).

The averages of the measured responses $\left(\mathrm{G}, \mathrm{T}_{50}\right.$, and $\mathrm{T}_{90}-\mathrm{T}_{10}$ ) at constant and alternating temperatures for 'Light Salmon' and 'Deep Salmon' are listed in Tables 1 and 2, respectively. Also listed are the coefficient estimates for the fitted regression equation, response $=$ $\mathrm{b}_{0}+\mathrm{b}_{\text {temp }}+\mathrm{b}$, temp $\mathrm{p}^{2}$, if a curvilinear trend was detected, or, if only a linear trend was present, response $=b_{0}+b_{1}$ temp. Results of the 
significance tests performed on the estimates are also reported in the tables. For alternating temperatures, the median temperature was used in fitting the regression equation.

Total G remained relatively constant for 'Light Salmon' (94\% to 98\%) and 'Deep Salmon' (83\% to $88 \%$ ) from 10 to $25 \mathrm{C}$ (Table 1). No seeds germinated at 30C (data not presented). For both cultivars, the number of days to $\mathrm{T}_{50}$ decreased significantly $(P<0.001)$ as germination temperatures increased from 10 to 20C. For both cultivars, temperature had a curvilinear effect: $\mathrm{T}_{50}$ increased slightly at $25 \mathrm{C}$ over that at $20 \mathrm{C}$. The span $\mathrm{T}_{90}-\mathrm{T}_{10}$ decreased for 'Light Salmon' as temperatures increased from 10 to $20 \mathrm{C}$, and then increased at 25C. For 'Deep Salmon', the span decreased linearly $(P<0.01)$ over the entire range of temperatures. Total $\mathrm{G}$ at alternating temperatures ranged from $93 \%$ to $99 \%$ for 'Light Salmon' and $67 \%$ to $82 \%$ for 'Deep Salmon' (Table 2). 'Light Salmon' total G showed no trend at the alternating temperatures studied. The number of days to $\mathrm{T}_{50}$ and the germination span $\left(\mathrm{T}_{90}-\mathrm{T}_{10}\right)$ decreased linearly for both cultivars as the median alternating temperature increased (Table 2).

The moisture content of 'Light Salmon' seed during storage affected germination in darkness at $20 \mathrm{C}$ (Table 3$)$. While a slight $(P=$ $0.07)$ linear decrease in total $G$ was observed for decreasing seed moisture content from $9 \%$ to $5 \%$, days to $\mathrm{T}_{50}$ and $\mathrm{T}_{90}-\mathrm{T}_{10}$ increased curvilinearly. The values of $\mathrm{T}_{50}$ and $\mathrm{T}_{90}-\mathrm{T}_{10}$ remained constant at $9 \%$ to $7 \%$ but increased at $6 \%$ and $5 \%$ moisture levels.
There were no significant changes in $\mathrm{G}$, $\mathrm{T}_{50}$, or $\mathrm{T}_{90}-\mathrm{T}_{10}$ after storing 'Light Salmon' or 'Deep Salmon' seeds at 5, 0, $-5,-10,-15$, or $-20 \mathrm{C}$ for 4 weeks (data not shown). 'Light Salmon' G varied among these storage temperatures from $99 \%$ to $97 \%, \mathrm{~T}_{50}$ from 3.3 to 3.6 days, and $\mathrm{T}_{90}-\mathrm{T}_{10}$ from 2.6 to 3.0 days. These results indicate that phlox seed are very cold-tolerant, and long-term storage at subzero temperatures may be possible.

The effects of SP and RH on $\mathrm{G}, \mathrm{T}_{50}$, and $\mathrm{T}_{90}$ $-\mathrm{T}_{10}$, at each storage temperature $(5,15$, or $25 \mathrm{C}$ ), are reflected in the plots of surface contours (Fig. 1) and the coefficient estimates of the fitted regression models (Table 4). Variation in the observed total $\mathrm{G}$, when taken across the four petri dishes, remained constant over the wide range (10\% to $100 \%$ ) of $G$ values

Table 1. Germination of phlox seed under constant temperatures in darkness.

\begin{tabular}{|c|c|c|c|c|c|c|c|c|c|c|c|c|}
\hline \multirow[b]{3}{*}{ Cultivar } & \multirow{3}{*}{$\begin{array}{c}\text { Temp } \\
\left({ }^{\circ} \mathrm{C}\right)\end{array}$} & \multicolumn{3}{|c|}{ Germination $^{x}$} & \multicolumn{8}{|c|}{ Regression coefficient estimates } \\
\hline & & \multirow{2}{*}{$\begin{array}{c}G \\
(\%)\end{array}$} & \multirow{2}{*}{$\begin{array}{c}\mathrm{T}_{50} \\
\text { (days) }\end{array}$} & \multirow{2}{*}{$\begin{array}{c}\mathrm{T}_{90}-\mathrm{T}_{10} \\
\text { (days) }\end{array}$} & \multicolumn{2}{|c|}{$\mathrm{G}$} & \multicolumn{3}{|c|}{$\mathrm{T}_{50}$} & \multicolumn{3}{|c|}{$\mathbf{T}_{90}-\mathbf{T}_{10}$} \\
\hline & & & & & $\mathbf{b}_{0}$ & $b_{1}$ & $\mathbf{b}_{0}$ & $b_{1}$ & $\mathrm{~b}_{2}$ & $\mathrm{~b}_{0}$ & $\mathbf{b}_{1}$ & $\mathrm{~b}_{2}$ \\
\hline \multirow[t]{4}{*}{ Light Salmon } & 10 & 97 & 8.6 & 5.3 & 95.1 & 0.08 & 22.6 & -1.83 & 0.04 & 12.2 & -0.88 & 0.02 \\
\hline & 15 & 94 & 4.5 & 3.6 & & & & & & & & \\
\hline & 20 & 98 & 3.3 & 2.6 & & & & & & & & \\
\hline & 25 & 97 & 3.4 & 2.8 & & & & & & & & \\
\hline Linear & & NS & $* * *$ & $* * *$ & & & & & & & & \\
\hline Quadratic & & NS & $* * *$ & $* * *$ & & & & & & & & \\
\hline \multirow[t]{4}{*}{ Deep Salmon } & 10 & 83 & 9.2 & 6.0 & 80.9 & 0.28 & 18.4 & -1.20 & 0.03 & 6.4 & -0.05 & \\
\hline & 15 & 86 & 6.7 & 5.5 & & & & & & & & \\
\hline & 20 & 88 & 5.8 & 5.2 & & & & & & & & \\
\hline & 25 & 87 & 6.0 & 5.1 & & & & & & & & \\
\hline Linear & & NS & $* * *$ & $*$ & & & & & & & & \\
\hline Quadratic & & NS & $* *$ & NS & & & & & & & & \\
\hline
\end{tabular}

${ }^{z}$ Data are means of 400 seeds.

Ns, *******Nonsignificant or significant at $P=0.05,0.01$, or 0.001 , respectively.

Table 2. Germination of phlox seed under alternating temperatures in darkness.

\begin{tabular}{|c|c|c|c|c|c|c|c|c|c|c|c|}
\hline \multirow[b]{3}{*}{ Cultivar } & & & \multicolumn{3}{|c|}{ YClinurativis } & \multicolumn{6}{|c|}{ 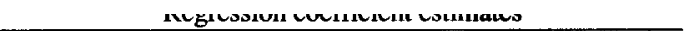 } \\
\hline & \multicolumn{2}{|c|}{ Temp $\left({ }^{\circ} \mathrm{C}\right)$} & \multirow{2}{*}{$\begin{array}{c}\mathrm{G} \\
(\%)\end{array}$} & \multirow{2}{*}{$\begin{array}{c}\mathrm{T}_{50} \\
\text { (days) }\end{array}$} & \multirow{2}{*}{$\begin{array}{c}\mathrm{T}_{90}-\mathrm{T}_{10} \\
\text { (days) }\end{array}$} & \multicolumn{2}{|c|}{$\mathbf{G}$} & \multicolumn{2}{|c|}{$T_{50}$} & \multicolumn{2}{|c|}{$T_{90}-T_{10}$} \\
\hline & Altemating & Median & & & & $\mathbf{b}_{\mathbf{0}}$ & $b_{1}$ & $b_{0}$ & $\mathbf{b}_{1}$ & $\mathbf{b}_{\mathbf{0}}$ & $b_{1}$ \\
\hline \multirow[t]{5}{*}{ Light Salmon } & $10-15$ & 12.5 & 98 & 5.3 & 3.1 & 99.2 & -0.12 & 6.4 & -0.11 & 4.4 & -0.10 \\
\hline & $10-20$ & 15.0 & 99 & 4.8 & 3.2 & & & & & & \\
\hline & $15-20$ & 17.5 & 96 & 4.1 & 2.5 & & & & & & \\
\hline & $15-25$ & 20.0 & 93 & 4.5 & 2.5 & & & & & & \\
\hline & $20-25$ & 22.5 & 99 & 4.1 & 2.2 & & & & & & \\
\hline Linear & & & NS & $* * *$ & $* * *$ & & & & & & \\
\hline Quadratic & & & NS & NS & NS & & & & & & \\
\hline \multirow[t]{5}{*}{ Deep Salmon } & $10-15$ & 12.5 & 82 & 7.1 & 5.3 & 97.5 & -1.18 & 8.7 & -0.12 & 7.1 & -0.13 \\
\hline & $10-20$ & 15.0 & 78 & 7.0 & 5.3 & & & & & & \\
\hline & $15-20$ & 17.5 & 80 & 6.2 & 4.8 & & & & & & \\
\hline & $15-25$ & 20.0 & 78 & 6.8 & 4.6 & & & & & & \\
\hline & $20-25$ & 22.5 & 67 & 5.7 & 4.1 & & & & & & \\
\hline Linear & & & $*$ & $* *$ & $* * *$ & & & & & & \\
\hline Quadratic & & & NS & NS & NS & & & & & & \\
\hline
\end{tabular}

${ }^{2}$ Data are the means of 400 seeds.

Ns,*******Nonsignificant or significant at $P=0.05,0.01$, or 0.001 , respectively.

Table 3. Effect of seed moisture content on the germination of 'Light Salmon' phlox seed at 20C in darkness.

\begin{tabular}{|c|c|c|c|c|c|c|c|c|c|c|c|}
\hline \multirow{3}{*}{$\begin{array}{l}\text { Seed } \\
\text { moisture } \\
(\%)\end{array}$} & \multicolumn{3}{|c|}{ Germination } & \multicolumn{8}{|c|}{ Regression coefficient estimates } \\
\hline & \multirow{2}{*}{$\begin{array}{c}G \\
(\%)\end{array}$} & \multirow{2}{*}{$\begin{array}{c}\mathrm{T}_{50} \\
\text { (days) }\end{array}$} & \multirow{2}{*}{$\begin{array}{c}\mathrm{T}_{90}-\mathrm{T}_{10} \\
\text { (days) }\end{array}$} & \multicolumn{2}{|c|}{ G } & \multicolumn{3}{|c|}{$\mathrm{T}_{50}$} & \multicolumn{3}{|c|}{$T_{90}-T_{10}$} \\
\hline & & & & $\mathrm{b}_{\mathrm{o}}$ & $\overline{b_{1}}$ & $b_{0}$ & $b_{1}$ & $\overline{\mathbf{b}_{2}}$ & $\overline{b_{0}}$ & $b_{1}$ & $b_{2}$ \\
\hline 9 & 98 & 5.7 & 2.5 & $80 . \overline{6}$ & 2.0 & 10.4 & -1.17 & 0.07 & 6.8 & -1.03 & 0.06 \\
\hline 8 & 98 & 5.6 & 2.5 & & & & & & & & \\
\hline 7 & 95 & 5.7 & 2.6 & & & & & & & & \\
\hline 6 & 94 & 5.9 & 2.9 & & & & & & & & \\
\hline 5 & 89 & 6.3 & 3.2 & & & & & & & & \\
\hline Linear & NS & $* * *$ & $* *$ & & & & & & & & \\
\hline Quadratic & NS & $* *$ & $*$ & & & & & & & & \\
\hline
\end{tabular}

ss, ${ }^{*,},{ }^{* *},{ }^{* *}$ Nonsignificant or significant at $P=0.05,0.01$, or 0.001 , respectively. 
observed. Estimated $\mathrm{G}$ values of $\geq 95 \%$ occurred after storage at $5 \mathrm{C}$ and $20 \%$ to $40 \% \mathrm{RH}$, while estimated $\mathrm{G}$ values $>90 \%$ occurred after 6 months of storage at $<75 \% \mathrm{RH}$ and up to 12 months of storage at $<60 \% \mathrm{RH}$ (Fig. 1A). Estimated $\mathrm{G}$ values declined when $\mathrm{RH}$ was $>40 \%$ for $>8$ months. At $15 \mathrm{C}$, germination was $100 \%$ after seed storage at $35 \%$ to $55 \%$ RH for $\leq 4$ months, but estimated $\mathrm{G}$ values decreased more rapidly at higher RHs $(\geq 60 \%)$ and longer storage periods ( $\geq 8$ months) at 15 than at $5 \mathrm{C}$ (Fig. 1B). Seeds stored at 25C had the lowest total $\mathrm{G}$ after storage among the three temperatures studied (Fig. 1C). At 25C, the highest estimated total $\mathrm{G}$ was only slightly $>80 \%$ at RHs $\leq 60 \%$ and SPs $<6$ months, or when seeds were stored $>6$ months at an $\mathrm{RH} \leq 35 \%$.

When seed was stored at $5 \mathrm{C}$, the estimated $\mathrm{T}_{50}$ was $<4$ at an RH $\leq 60 \%$ and SPs $<6$ months (Fig. 1D). The $\mathrm{T}_{50}$ remained $<4$ days for all SPs when RHs were $\leq 40 \%$. Seeds stored at $15 \mathrm{C}$ had slightly higher $\mathrm{T}_{50}$ values than at $5 \mathrm{C}$ for similar RHs and SPs (Fig. 1E). The $\mathrm{T}_{50}$, remained low ( $\leq 4$ days) over 12 months of storage at $<20 \% \mathrm{RH}$, or at $0 \%$ to $60 \%$ RI-1 for an SP of $<5$ months. At $25 \mathrm{C}, \mathrm{T}_{50}$ was lowest (14 days) only after storage for $<5$ months at an $\mathrm{RH}<40 \%$ (Fig. 1F). The estimated $\mathrm{T}_{50}$ following storage at $25 \mathrm{C}$ increased dramatically as SPs and RHs increased to $>8$ months and $>60 \%$, respectively.

The $T_{90}-T_{10}$ span increased with high SPs and RHs, at which similar patterns developed at the three storage temperatures (Fig. 1G-I). The lowest $\mathrm{T}_{90}-\mathrm{T}_{10}(12$ days) occurred after $<4$ months storage at $5 \mathrm{C}$ or after $<3$ months at $15 \mathrm{C}$ at $10 \%$ to $60 \% \mathrm{RH}$ (Fig. $1 \mathrm{G}$ and $\mathrm{H}$ ). At $5 \mathrm{C}$, increasing seed SP had little or no effect on $\mathrm{T}_{90}-\mathrm{T}_{10}$ spans at an $\mathrm{RH}<40 \%$ (Fig. $1 \mathrm{G}$ ); however, at $15 \mathrm{C}, \mathrm{T}_{90}-\mathrm{T}_{10}$ remained low (14 days) over the range of RHs only with $<4$ months storage (Fig. $1 \mathrm{H})$. At $25 \mathrm{C}$, the lowest $\mathrm{T}_{90}-\mathrm{T}_{10}$ ( $\leq 4$ days) occurred after storage for $<4$ months for all RHs. Also, at 25C, a curvilinear effect on $\mathrm{T}_{90}-\mathrm{T}_{10}$ was found over the range of storage periods. This result indicated that long and short SPs had lower $T_{90}-T_{10}$ than intermediate SPs (Fig. 1I).
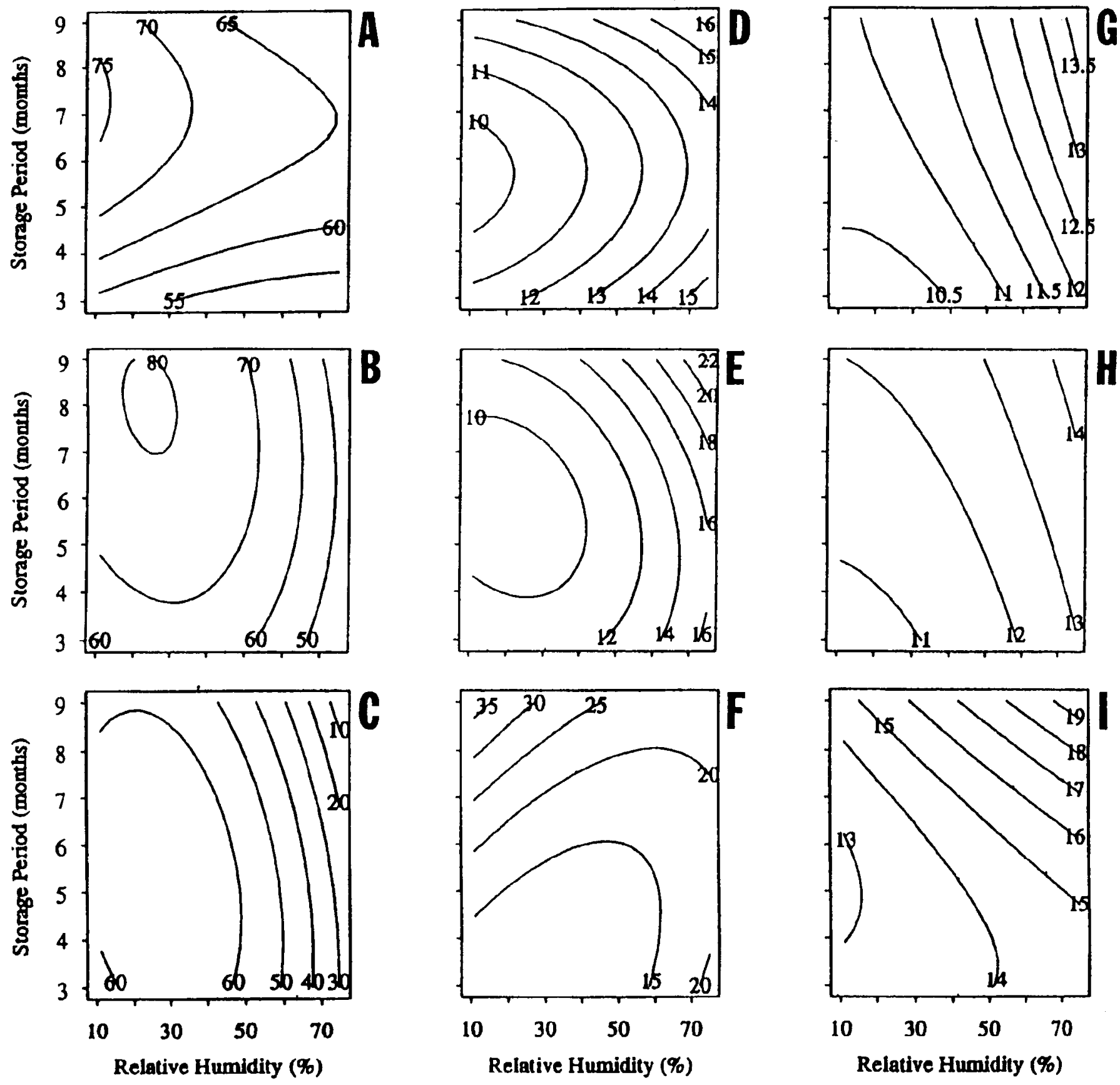

Fig. 1. Contour plots for total germination percentages (A-C), days to 50\% of final germination (D-F), and days between $10 \%$ and $90 \%$ germination (G-I) for 'Light Salmon' phlox seeds germinated at 20C following storage at 5C and $11 \%$ to $95 \%$ relative humidity for 3 to 12 months (A, D, G), 15C (B, E, H), or 25C $(\mathbf{C}, \mathbf{F}, \mathbf{I})$. Regression equations used to generate these plots are listed in Table 4. 
Production and Culture

Table 4. Coefficient estimates and significance levels $\operatorname{Pr}\left(|\mathrm{T}|>\mathrm{t}_{\mathrm{a}}\right)=\alpha$ for the fitted regression models. Estimated response $=B_{0}+B_{1} S P+B_{2} R H+B_{3} S P \times R H+$ $\mathrm{B}_{4} \mathrm{SP}^{2}+\mathrm{B}_{5} \mathrm{RH}^{2}$.

\begin{tabular}{|c|c|c|c|c|c|c|c|c|c|}
\hline \multirow[b]{2}{*}{ Response } & \multirow{2}{*}{$\begin{array}{l}\text { Temp } \\
\left({ }^{\circ} \mathrm{C}\right)\end{array}$} & \multicolumn{6}{|c|}{ Coefficient estimates } & \multirow[b]{2}{*}{$R^{2}$} & \multirow[b]{2}{*}{ Figure } \\
\hline & & $b_{0}$ & $b_{1}$ & $b_{2}$ & $b_{3}$ & $b_{4}$ & $b_{5}$ & & \\
\hline \multirow[t]{6}{*}{$\overline{\mathrm{G}}$} & 5 & 90.83 & 0.45 & 0.33 & -0.02 & & -0.004 & $\overline{0.6369}$ & $1 \mathrm{~A}$ \\
\hline & & & 0.0685 & 0.0002 & 0.0002 & & 0.0001 & & \\
\hline & 15 & 70.79 & 3.92 & 1.19 & -0.08 & -0.18 & -0.01 & 0.8698 & $1 \mathrm{~B}$ \\
\hline & & & 0.0044 & 0.0001 & 0.0001 & 0.0362 & 0.0001 & & \\
\hline & 25 & 90.26 & -0.42 & 0.68 & -0.04 & & -0.01 & 0.6514 & $1 \mathrm{C}$ \\
\hline & & & 0.4385 & 0.0247 & 0.0109 & & 0.0248 & & \\
\hline \multirow[t]{6}{*}{$T_{50}$} & 5 & 4.22 & -0.05 & -0.06 & 0.004 & & $6.3 \times 10^{-4}$ & 0.8411 & 1D \\
\hline & & & 0.0551 & 0.0001 & 0.0001 & & 0.0001 & & \\
\hline & 15 & 4.26 & -0.02 & -0.06 & 0.004 & & $6.2 \times 10^{-4}$ & 0.8912 & $1 \mathrm{E}$ \\
\hline & & & 0.3438 & 0.0001 & 0.0001 & & 0.0001 & & \\
\hline & 25 & 4.36 & 0.02 & -0.10 & 0.008 & & $1.4 \times 10^{-3}$ & 0.9071 & $1 F$ \\
\hline & & & 0.6118 & 0.0001 & 0.0001 & & 0.0001 & & \\
\hline \multirow[t]{6}{*}{$T_{90}-T_{10}$} & 5 & 1.82 & 0.38 & -0.07 & 0.003 & $-2.4 \times 10^{-2}$ & $9.7 \times 10^{-4}$ & 0.7802 & $1 G$ \\
\hline & & & 0.0031 & 0.0001 & 0.0031 & 0.0021 & 0.0001 & & \\
\hline & 15 & 0.74 & 0.61 & -0.04 & 0.004 & -0.04 & $5.0 \times 10^{-4}$ & 0.9048 & $1 \mathrm{H}$ \\
\hline & & & 0.0001 & 0.0025 & 0.0001 & 0.0001 & 0.0001 & & \\
\hline & 25 & -1.05 & 1.21 & 0.006 & 0.006 & -0.07 & & 0.8662 & 1I \\
\hline & & & 0.0001 & 0.6420 & 0.0014 & 0.0001 & & & \\
\hline
\end{tabular}

Having seed that has high total $G$ and rapid and uniform seedling emergence is important to commercial bedding plant producers. Hartmann et al. (1990) reported that alternating daily temperatures $10 \mathrm{C}$ improved seed germination in species requiring both high and low temperatures. Our results showed that alternating daily temperatures did not improve phlox germination. Similar total Gs were found for 'Light Salmon' $(\mathrm{G} \geq 93 \%)$ seeds germinated at similar constant or alternating temperatures, while 'Deep Salmon' seeds germinated better $(\mathrm{G} \geq 83 \%)$ at constant temperatures. The $\mathrm{T}_{50}$ values for 'Light Salmon' at constant 20 or $25 \mathrm{C}$ were shorter than at alternating temperatures, but generally no differences were found among the $T_{50}$ values for 'Deep Salmon'. $\mathrm{T}_{90}-\mathrm{T}_{10}$ for both cultivars was similar at constant and alternating germination temperatures, ranging from 2.2 to 5.3 for 'Light Salmon' and 4.1 to 6.0 for 'Deep Salmon'. No phlox seed germinated at constant 30C, while alternating $20 / 30 \mathrm{C}$ or $25 / 30 \mathrm{C}$ reduced G to $58 \%$ and $36 \%$ for 'Light Salmon' and 'Deep Salmon', respectively, and delayed $\mathrm{T}_{50}$ and $\mathrm{T}_{90}-\mathrm{T}_{10}$ (data not presented). Our results explain the low total and irregular germination that occurs when direct-seeded phlox are germinated in warm greenhouses.

In seed production, freshly harvested seeds are dried to low moisture content before they are stored and shipped in sealed packages. It is important to know if the seed moisture content used by seed producers can delay germination or reduce viability or vigor. Our study showed that $\mathrm{G}$ was similar when phlox seed moisture content was between $9 \%$ and $5 \%$. Similarly, $\mathrm{T}_{50}$ or $\mathrm{T}_{90}-\mathrm{T}_{10}$ was unaffected at $9 \%$ to $6 \%$ seed moisture content. At 5\% moisture content, however, $\mathrm{T}_{50}$ and $\mathrm{T}_{90}-\mathrm{T}_{10}$ were higher than the corresponding values at higher moisture levels. Bewley and Black (1982) associated cell membrane deterioration with delayed and irregular germination of seeds after they were stored at low moisture content. Justice and Bass (1978) reported that delayed and irregular germination are early indicators of embryo injury. In our research, no embryo injury was observed in histochemically prepared tissue.

'Light Salmon' seed stored for 12 months at $5 \mathrm{C}$ and $11 \%, 34 \%, 52 \%, 75 \%$, or $95 \% \mathrm{RH}$ contained $6.5 \%, 7.8 \%, 9.7 \%, 11.2 \%$, and $13.6 \%$ moisture, respectively. The regression analyses estimated that low to intermediate RHs (10\% to $50 \%$ ) and SPs ( $\leq 6$ months) produced the highest total germination percentages and shortest $\mathrm{T}_{50}$ and $\mathrm{T}_{90}-\mathrm{T}_{10}$ at the three temperatures. The smallest amount of change in these germination responses occurred at low RHs (10\% to $40 \%)$, even when the seeds were stored for 12 months. Our results indicated that the slowest deterioration of phlox seed during storage occurred at a seed moisture content $<6 \%$, the low end of the seed desiccation tolerance range. The highest $\mathrm{G}$ and shortest $\mathrm{T}_{50}$ and $\mathrm{T}_{90}-\mathrm{T}_{10}$ generally resulted after seeds were stored at $5 \mathrm{C}$.

\section{Literature Cited}

Ball, V. 1985. Ball red book: Greenhouse growing. 14th ed. Reston Publ. Co., Reston, Va.
Becker, R.A., J.M. Chalmers, and A.R. Wilks. 1988. The new S language. Wadsworth \& Brooks/ Cole, Pacific Grove, Calif.

Bewley, J.D. and M. Black. 1982. Physiology and biochemistry of seeds. Springer-Verlag, New York.

Cathey, H.M. 1976. Seed germination, p. 47-54. In: J.W. Mastalerz (ed.). Bedding plants, 2nd ed. Pennsylvania Plower Grower, University Park, $\mathrm{Pa}$.

Copeland, L.O. 1976. Principles of seed science and technology. Burgess, Minneapolis.

Furutani, S.C., B.H. Zandstra, and H.C. Price. 1985. Low temperature germination of celery seeds for fluid drilling. J. Amer. Soc. Hort. Sci. 110:149-153.

Hartmann, H.T., D.E. Kester, and F.T. Davies, Jr. 1990. Plant propagation principles and practices. 5th ed. Prentice Hall, Englewocd Cliffs, N.J.

Heydecker, W. and A. Hendy. 1975. Pretreating bedding plant seed for instant germination. U.K. Commercial Grower 4163:613-615.

Jana, B.K. and B.C. Dass. 1984. Effects of seed treatment with growth regulators on germination of seasonal flowers. J. South Indian Hort. $32: 110-112$.

Justice, O.L. and L.N. Bass. 1978. Principles and practices of seed storage. U.S. Dept. of Agriculture, Washington, D.C. Hdbk. 506.

SAS Institute. 1985. SAS user's guide: Statistics. 5th ed. SAS Institute, Cary, N.C.

Shirokova, A.V., V.P. Baigozina, and M.S. Zorina 1977. Effect of temperature and microelements on the sowing quality of Phlox drummondii seeds. Glavnogo Botanicheskogo Sada Bul. 103:91-93. 